\title{
MODELLING AND ANALYSIS OF DYNAMIC STATES OF THE LEAD-ACID BATTERIES IN ELECTRIC VEHICLES
}

\author{
MODELOWANIE I ANALIZA STANÓW DYNAMICZNYCH AKUMULATORÓW \\ KWASOWO-OŁOWIOWYCH W POJAZDACH ELEKTRYCZNYCH
}

\begin{abstract}
The paper presents the aspects related to the modelling of lead-acid batteries, including the description of the process of equivalent model parameter estimation. On top of this, the subject of the discussion included the issues which concern the analysis of vehicle energy consumption. The examples of calculations for the estimation of the model parameters were presented and on their basis, the detailed analysis of the battery's behaviour while driving an electric vehicle was carried out. The tests were performed based on the recorded velocities of the vehicle moving within the built-up area in heavy traffic conditions. The behaviour of the battery was evaluated and the application of the hybrid energy storage consisting of battery and supercapacitor was proposed.
\end{abstract}

Keywords: lead-acid battery modelling, model parameters estimation, supercapacitor, electric vehicles.

\begin{abstract}
W pracy przedstawiono problematykę modelowania akumulatorów kwasowo-ołowiowych, wraz z opisem procesu estymacji parametrów modelu ekwiwalentnego. Omówiono także zagadnienia dotyczące analizy energochłonności pojazdów samochodowych. Przedstawiono przykładowe obliczenia dotyczące estymacji parametrów modelu i na ich podstawie dokonano szczegótowej analizy zachowania się akumulatora podczas jazdy samochodu elektrycznego. Badania przeprowadzono na podstawie zarejestrowanych prędkości pojazdu poruszającego się na terenie zabudowanym w okresie dużego natężenia ruchu. Dokonano oceny zachowania się akumulatora i zaproponowano zastosowanie hybrydowego magazynu energii zbudowanego z akumulatora $i$ superkondensatora.
\end{abstract}

Stowa kluczowe: modelowanie akumulatorów kwasowo-ołowiowych, estymacja parametrów modelu, superkondensator, samochody elektryczne.

\section{Introduction}

For hundreds of years, the people's need for mobility has contributed to the development of various types of vehicles, which were usually powered by draught animals or humans. However, rapid industrial development in the $19^{\text {th }}$ century resulted in numerous solutions, which used mechanical drives powered mainly by heating fuels. Initially, these were steam vehicles, and later on, the whole range of various internal combustion engines was developed. The vehicle solutions powered by electric engines also appeared during that period, but electric drive systems were hardly used in vehicles because of limited abilities to store electric energy in mobile systems. For this reason, the $20^{\text {th }}$ century is the period dominated by vehicles powered by heating fuels [16].

However, the use of non-renewable energy sources has this one obvious disadvantage that such sources someday will be exhausted. For this reason, wind power plants and photovoltaic panels appear at single-family houses, wind and photovoltaic farms are built on fields and almost all well-known companies that manufacture cars boast with the offered electric and hybrid ecological vehicles [5, 16, 19, 21]. In comparison with internal combustion engine vehicles, they have many advantages - they do not emit substances detrimental to the environment, are much more efficient (their efficiency exceeds $90 \%$, while internal combustion engine vehicles are characterised by the efficiency ranging between $20 \%$ and $30 \%$ ), their construction is much simpler and cheaper to operate and - what is also important - they can regenerate energy during the braking process $[16,21]$.

Not only do the electric vehicles become more and more popular for ecological reasons, but also as a consequence of the technological development of systems used for energy storing. The recent years mark the appearance of the whole range of various kind of batteries whose parameters allow their use in numerous mobile systems, including cars. Unfortunately many of these solutions are much more expensive than popular lead-acid batteries. Additionally, modern batteries often require the application of systems that control their performance (values and distribution of voltages and currents on the respective cells and quite importantly, also the temperature). Failure to observe the limit parameters may lead to their premature aging, and also to a dangerous fire. For this reason, and also because of their low price, lead-acid batteries, whose construction technology is also subject to continuous improvement, are still used. Owing to this, they become more durable and resistant to operating conditions that deviate from nominal operating conditions [16].

Unfortunately, the main disadvantage of the lead-acid batteries is the significant impact of high currents on their life. So far, the solution for this problem included just an increase the number of cells (total capacity), however, in the case of the mobile solutions, this is related to a cumbersome increase in weight. Another solution is the use of the system allowing for the reduction of high currents that have a deteriorating effect, for instance, the hybrid energy storage consisting of a battery and a supercapacitor. Such a system does not have great abilities to store energy (energy density), yet it can return it at a relatively short time (power density). In view of differences in the principle of operation of both storages, voltages on their terminals in various states may differ significantly, therefore, power electronics systems which control their performance are required for cooperation 
between these storages $[8,10]$. In such solutions, it is possible to use various algorithms which control the energy flow and which can be supervised in professional solutions by complex optimization algorithms [17] using e.g. genetic algorithms [3, 13, 14]. In order to design and control energy storages, it is necessary to be familiar with the behaviour of such storages (especially the dynamics of changes in the values of currents, voltages and present amount of stored energy). In view of the diversity of electrochemical processes, which take place in the lead-acid battery - being the main energy source in such systems - this is a very difficult issue, especially with regards to vehicles, whose power demand is quasi-stochastic.

For this reason, many scientific works are presently devoted to the analysis of energy consumption in electric vehicles, and also to the creation of mathematical models for estimation of the vehicle power demand [21]. Contemporary scientific works concentrate on mathematical-physical models intended for analysis of energy consumption of vehicles and optimization of energy management in vehicle power supply systems. A frequently applied methodology which serves the purpose of estimation of the vehicle energy consumption is the development of the model based on vehicle dynamics equations and data measured during the real driving sessions. Such an approach was applied in works $[4,21,12]$. The works present vehicle models intended for energy consumption analysis and demonstrate that the electric vehicle power demand may be described by means of the normal distribution in a specific range of variability of parameters such as velocity, acceleration or road slope [21]. A different approach was presented in paper [7], in which the quantitative correlations between the kinematic vehicle parameters were discussed to estimate the energy consumption of the electric vehicle.

Problems related to the determination of parameters of the electric energy storage model are also important and valid subjects. These issues constitute an important part of the topics regarding modelling, because in order to carry out the analysis of behaviour of a selected energy storage with as high accuracy as possible (in particular, this refers to electrochemical storages), the parameters of its model must be calibrated. As examples of works dealing with these issues, one can present $[1,9,11,15,22]$.

It must also be emphasised that an important aspect of operation of electric vehicles is the proper management of electric energy flow between the electric power train and the electric energy storage, especially in the systems with the hybrid energy storage. The example of such solutions is presented in works $[8,9,10]$, where the dynamic models of energy storages such as batteries or supercapacitors are described.

Therefore, this paper deals with the issue of modelling of leadacid batteries and optimal selection of the hybrid energy storage, as well as energy flows in electric vehicles. The mathematical model of a battery and the method of estimation of its parameters are described in detail. The calculation algorithm takes into account the driving characteristics of a real vehicle moving within an urban area, recorded by means of the developed and designed drive recorder.

\section{Energy consumption vehicles}

In order to estimate the energy demand of a vehicle, it is necessary to analyse forces acting on it. In the case of vehicles moving with variable velocity (e.g. in the case of cars), a significant amount of the energy results from the necessity to accelerate and brake. Additionally, each moving vehicle is affected by forces resulting from the aerodynamic resistance force as well as rolling friction force. Both of these forces depend on many factors such as the shape of the vehicle, its frontal surface, type of pavement and even tyre width and pressure $[15,20]$.

The resultant force acting on the vehicle, which causes a change in its velocity, is relatively easy to estimate based on the instantaneous velocity of the vehicle under consideration, therefore the energy demand analysis for vehicles is usually carried out, by starting with the determination of the driving force $(F)$ understood as the difference between the resultant force $\left(F_{D}\right)$ and the aerodynamic resistances $\left(F_{A}\right)$ and rolling resistances $\left(F_{R}\right)$ :

$$
F=F_{D}-F_{A}-F_{R}
$$

The rolling resistance can be estimated on the basis of the following equation $[12,15,16,21]$ :

$$
F_{R}=m g f_{t 0}\left(1+K v^{2}\right)
$$

where: $m$ - vehicle mass, $g$ - standard gravity acceleration, $v$ - speed of the vehicle, $K$ - additional rolling resistance coefficient (for asphalt surfaces $\left.K=5 \cdot 10^{-5} \mathrm{~s}^{2} / \mathrm{m}^{2}\right), f_{t 0}$ - rolling resistance coefficient at low speeds, which is determined by performing the drag racing test and calculated by the following formula $[12,15,16,21]$ :

$$
F_{t 0}=\frac{v_{b}^{2}}{2 g S_{t}}
$$

where: $v_{b}$ - initial speed of the vehicle, $S_{t}-$ the rolling distance of the vehicle.

Usually, for a passenger vehicle moving on an asphalt road, the rolling resistance coefficient for low speeds is assumed to range between 0,012 and 0,014 [15].

$$
F_{A}=\frac{1}{2} \rho \mathrm{c}_{x} A v_{r}^{2}
$$

where: $\rho$ - air density (for normal conditions of $0^{\circ} \mathrm{C}$ and the pressure of $1013 \mathrm{hPa}$, dry air density is about $\left.1.29 \mathrm{~kg} / \mathrm{m}^{3}\right), c_{x}$ - air resistance coefficient in the longitudinal direction - it depends on the shape of the vehicle and ranges between $25 \%$ and $45 \%, A$ - coefficient of a vehicle frontal surface area, $v_{r}$ - the speed of the vehicle in relation to the air.

Having the thermal resistance value, the given value of the instantaneous velocity $v$ of the car and assuming the given level of the drive system efficiency $\eta$, it is possible to estimate the driving forces acting on the vehicle, the instantaneous power $P$ and the energy $E$ (equations 5 and 6) needed to take a given route $S$ in the specified time $t$ [15].

$$
\begin{gathered}
E=\frac{F S}{\eta} \text { or } E=\frac{F t v}{\eta} \\
P=\frac{F v}{\eta} \text { or } P=\frac{E}{t}
\end{gathered}
$$

\section{Modelling of lead-acid batteries}

The task of mathematical models is to solve a broad range of issues from many fields of science and different situations in everyday life. In the case of batteries, they allow the determination of desired values during the simulation which maps the real conditions with satisfactory accuracy, without a need to establish any measuring systems. They also allow the estimation of the state of charge and the degradation of the batteries, and even the determination of parameters which would be difficult or even impossible to measure in real ob- 
jects. Values obtained as a consequence of performed analytical calculations on the mathematical model are often used to select and optimize the efficiency of energy storages irrespective of the nature of the device, which cooperates with the storage and its structure $[1,9,11,16]$.

The mathematical model of energy storages constitutes an electric circuit which represents a single cell of the modelled storage. In order to obtain a higher capacity of the storage, the cells are connected in serial-parallel configurations. For loads characterised by the power consumption with a constant value at a relatively short time, it is possible to apply a simplified mathematical model, which treats the battery as an ideal or real voltage source. However, when there is a need to consider the operating conditions of the real battery, the model turns out to be insufficient.

The electric circuit which reflects the operation of the real battery in a representative manner is the electric circuit which contains the serial connection of the voltage source $(E)$ and the non-linear resistor $(R)$ (Fig. 1).

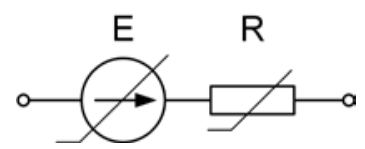

Fig. 1. Simple model of lead-acid battery

Inner resistance represents the resistance of electrode plates and electrolyte, which map the chemical phenomena taking place in electrode plates and electrolyte, and also the polarization resistance, which expresses the relative change in the polarization voltage on the cell terminals during the current flow, referred to rated voltage $[2,6]$. The non-linearity of the resistor results from a high variability of chemical processes taking place in the cell (which depend on the load current, current flow time, temperature and electrical capacity) $[2,6]$.

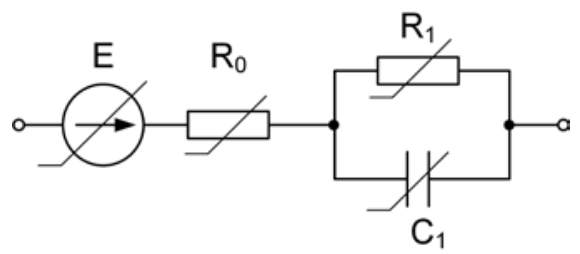

Fig. 2. Battery electric equivalent model

Very frequently, in engineering applications, there is a need to determine the properties of electrochemical sources while applying the current load with the amplitude variable in time, at the set temperature and known value of the available charge accumulated in the battery. For this purpose, the equivalent circuit of the cell, which additionally contains the branch of RC elements connected in parallel is used. Owing to this branch, it is possible to map the inertial behaviour of the battery in dynamic states. The electric circuit which enables the determination of operating parameters of the battery in dynamic states is presented in figure $2[2,6]$.

In long-lasting analyses of the behaviour of a cell or at longlasting load of high currents with a value that significantly varies in time, it is necessary to use the mathematical model which takes into consideration the thermal phenomena (the effect of temperature on parameters), as well as phenomena related to the self-discharge process occurring in the battery. The accuracy of the applied model is also affected by the number of selected RC branches (dependent on the degree and dynamics of load variation). However, it must be emphasised that as a consequence of the appearance of a large number of RC branches in the model, the difficulty in solving the system of

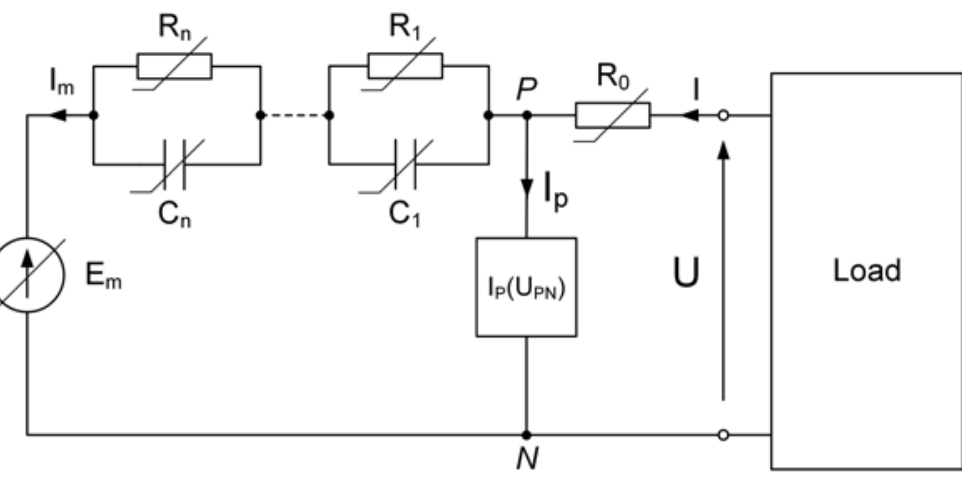

Fig. 3. Battery electric equivalent model with a parasitic branch (n-th order) $[2,6]$

equations that describes the wiring diagram and the difficulty in the proper estimation of initial values of parameters increase (model estimation). The electric circuit of the $n$-th order lead-acid battery cell is presented in figure 3 .

In order to carry out the analysis of the battery's behaviour, it is necessary to know the useful capacity of the battery, which depends on the load current, current flow time and temperature - formula $[2,6]$ :

$$
C(I, T)=\frac{K_{C} C_{0^{*}}\left(1+\frac{T_{e}}{-T_{f}}\right)^{\varepsilon}}{1+\left(K_{C}-1\right)\left(\frac{I}{I_{n}}\right)^{\delta}}
$$

where: $K_{C}, C_{0^{*}}, \varepsilon, \delta$ - constants determined on the basis of battery specifications, $T_{e}$ - electrolyte temperature, $T_{f}$ - electrolyte freezing point, $I$ - battery load current, $I_{n}$ - battery rated current.

The parameters which have the decisive influence on the battery performance are values related to the equivalent circuit. Their number depends on the selected circuit, and for the model variant with two branches, (the model presented in figure 3), they are determined by the following relationships $[2,6]$ :

$$
R_{0}=R_{00}\left(1-A_{0}(1-S O C)\right)
$$

$$
R_{1}=-R_{10} \ln (D O C)
$$

$$
C_{1}=\frac{\tau_{1}}{R_{1}}
$$

$$
R_{2}=R_{20} \frac{\exp \left[A_{21}(1-S O C)\right]}{1+\exp \left(\frac{A_{22} I_{m}}{I_{n}}\right)}
$$

$$
C_{2}=\frac{\tau_{2}}{R_{2}}
$$

$$
E_{m}=E_{m 0}-K_{E}\left(273.15+T_{e}\right)(1-S O C)
$$

where: $R_{00}, R_{10}, \mathrm{R}_{20}, \mathrm{~A}_{0}, \mathrm{~A}_{21}, \mathrm{~A}_{22}, K_{E}$ - constants which depend on the construction and state of the battery, determined on the basis of the estimation (described in section 4 ), $\tau_{1}, \tau_{2}$ - time constants of the RC branch, $I_{m}$ - the current of the battery's main branch (see Fig. 3), 
$E_{m 0}$ - open circuit battery voltage at $0^{\circ} \mathrm{C}$, and the battery state of charge (SOC) and depth of charge (DOC) during the discharging or charging are described by equations (14) and (15) $[2,6]$ :

$$
\begin{gathered}
S O C=1-\frac{\int_{0}^{t} i_{m}(t) d t}{C(0, T)} \\
D O C=1-\frac{\int_{0}^{t} i_{m}(t) d t}{C\left(I_{\text {avg }}, T\right)}
\end{gathered}
$$

where: $i_{m}$ - current flowing through the main branch, $C(0, T)$ - no-load battery capacity at temperature $T, C\left(I_{a v g}, T\right)$ - battery capacity referred to the average discharge or charge current $I_{\text {avg }}$ at set temperature $T$.

\section{Estimation of the battery model parameters}

The battery model presented in the preceding section is used to analyse the operation of various batteries in dynamic states, but its respective parameters differ significantly depending on many factors related to the type, construction, and state of the battery. In order to analyse the performance of a specific battery while driving an electric vehicle, it is necessary to carry out a series of tests which allow for determination of the respective elements of the battery equivalent circuit and the constants related to it (discussed in section 3) [12].

For the purposes of the tests, the NPCG18 12 V 18 Ah Gel Deep Cycle traction battery manufactured by TOYAMA was selected. The measurements were made using Potentiostat VMP3 BioLogic. The tests were started with the determination of the real battery capacity for different discharge times by means of the constant current method (CC) under rated conditions - the 20-hour capacity was estimated at the level of $20.25 \mathrm{Ah}$.

As the temperature of electrolyte has a significant impact on the behaviour of electrochemical batteries, during the analysis of the battery operation, it is necessary to take into account the thermal conditions (heating and cooling) of the battery, related both to the electrochemical processes taking place inside the battery and resulting from the heat transfer to the surrounding environment. In order to estimate the amount of heat transferred to the surrounding environment, the heat capacity of the battery and its thermal resistance were determined. The precise determination of these parameters in real conditions of battery performance is extremely difficult. In the case of vehicles, they depend on many conditions such as ambient temperature, tightness of the housing inside which there is the battery, vehicle velocity, and even wind velocity. Moreover, the so-called bat-

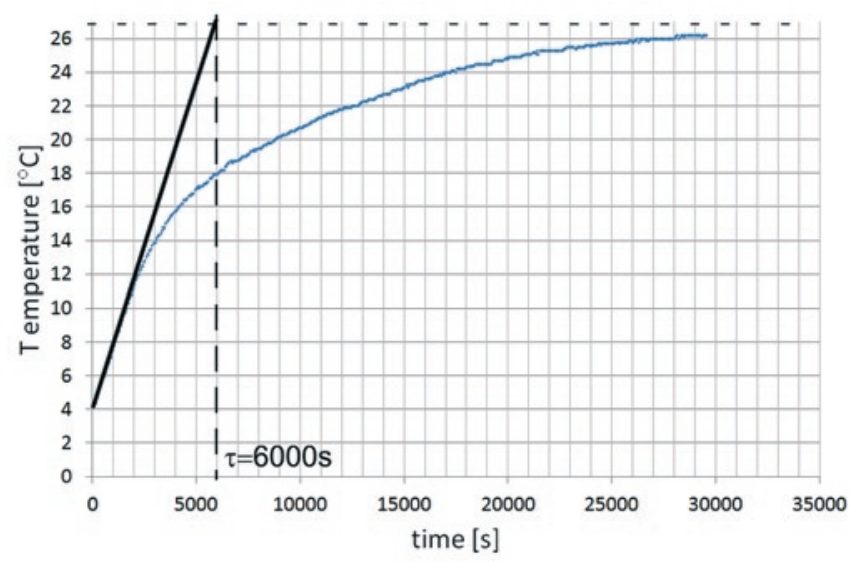

Fig. 4. Electrolyte temperature vs time tery managing systems (BMS) are also used frequently; they enable the additional cooling or heating of the batteries if required. Despite this, laboratory tests consisting in the estimation of the value of thermal parameters were conducted in order to verify the model correctness - by comparing the obtained electrolyte temperature results and the measured values. The heat capacity of the battery was determined by means of the heat balance method (using the calorimeter), and the thermal resistance was determined by analysing the time constant of the battery cooled down to the temperature of $4.2^{\circ} \mathrm{C}$ in the laboratory premises with the constant temperature of $27^{\circ} \mathrm{C}$ (Fig. 4). The temperature was measured by the Graphtec GL 800 temperature recorder equipped with ceramic PT100 probes, by fixing them nearby the battery terminal (so as to approximate the temperature as closely to the electrolyte temperature as possible). The determined value of the heat capacity of the battery amounts to about $1.2 \mathrm{~kJ} / \mathrm{K}$, and thermal resistance is $5 \mathrm{~K} / \mathrm{W}$.

In the next part of the tests, the voltage on battery terminals and electrolyte temperature were recorded during the cyclic (fourfold) discharge at current with the value of $4.07 \mathrm{~A}$ for $3600 \mathrm{~s}$, then the discharge process was interrupted for $3600 \mathrm{~s}$. The battery current and voltage measurements were presented in figures 5 and 6 with the dotted line.

In view of the fact that in the situation under consideration the battery, whose model parameters were determined, is supposed to power the electric vehicle, the parasitic branch, which represents the self-discharge effect, was omitted during the estimation. The process is no significance to the obtained simulation results, as it is very slow in comparison to the considered travelling time of the electric vehicle - currents flowing through this branch are measured in micro- or even nanoamperes $[2,6]$.

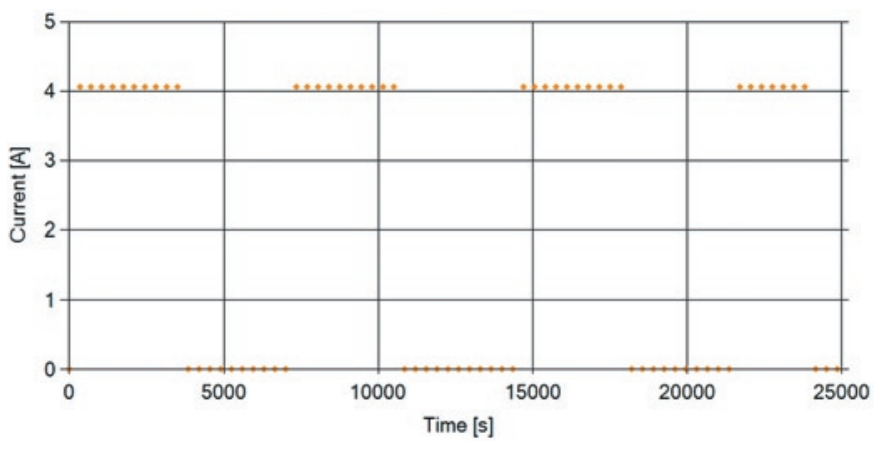

Fig. 5. Battery current vs time

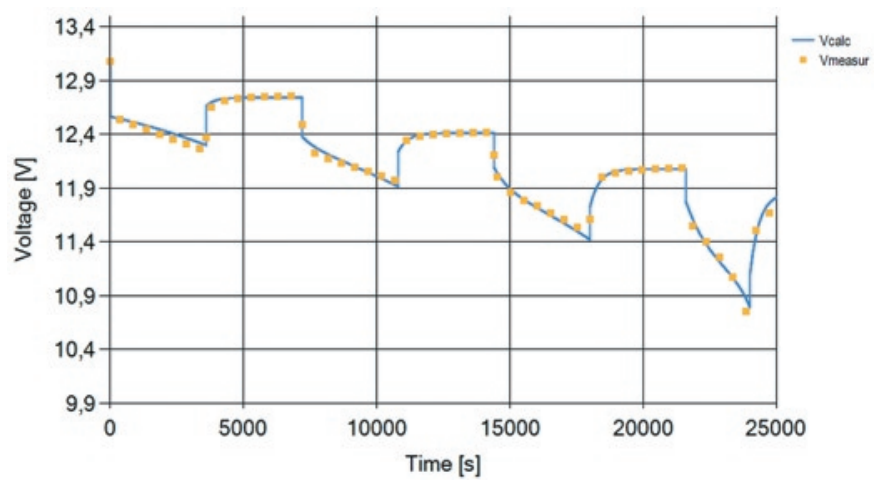

Fig. 6. Voltage on battery terminals vs time

The next step was the development of the computer application in the MS Visual Studio environment, which is supposed to serve the purpose of estimation of the battery model parameters. The application carries out the analysis of the values of momentary currents and voltages in the electric circuit which represents the equivalent circuit 
of the battery, for different values of model parameters. Ultimately it optimizes the sought parameters in such a way as to bring the voltage values on the battery terminals resulting from the analysis as close as possible to the measured values - using the mean square approximation. Because of high values of time constants of the electric circuit, the analysis of the electric values of this circuit must be treated as the analysis of transients, which, according to the electric circuit methods require that the system of differential equations be solved (16). These equations have been solved on many occasions, each time changing the values of parameters of the mathematical model by means of the range searching method using decreasing step sizes. The obtained results of the determined model parameters are included in table 1, while figure 6 presents the results of the analysis of voltages on terminals of the battery equivalent circuit (the measured ones with the dashed line and the calculated ones with the continuous line). The calculated values were determined on the basis of parameters obtained during the optimization:

$$
\left\{\begin{array}{c}
i_{m}(t)=i_{R 1}(t)+i_{C 1}(t) \\
i_{m}(t)=i_{R 2}(t)+i_{C 2}(t) \\
u(t)=e_{m}(t)-i_{m}(t) R_{1}-i_{m}(t) R_{2}-i_{m}(t) R_{0} \\
C_{1} \frac{d u_{1}(t)}{d t}=\frac{u_{1}(t)}{R_{1}} \\
C_{2} \frac{d u_{2}(t)}{d t}=\frac{u_{2}(t)}{R_{2}}
\end{array}\right.
$$

Table 1. Parameters archived during the estimation

\begin{tabular}{|c|c|c|c|c|c|c|c|c|c|c||}
\hline \hline $\mathrm{E}_{\mathrm{m} 0}[\mathrm{~V}]$ & $\mathrm{R}_{00}[\Omega]$ & $\mathrm{A}_{0}$ & $\mathrm{R}_{10}[\Omega]$ & $\mathrm{R}_{20}[\Omega]$ & $\mathrm{A}_{21}$ & $\mathrm{~A}_{22}$ & $\tau_{1}[\mathrm{~s}]$ & $\tau_{2}[\mathrm{~s}]$ & $\mathrm{K}_{\mathrm{e}}\left[\mathrm{V} /{ }^{\circ} \mathrm{C}\right]$ & $\mathrm{K}_{\mathrm{C}}$ \\
\hline 2.18 & 0.0124 & -0.013 & 0.009 & 0.21 & -6.6 & -0.7 & 450 & 50 & $10.5 \cdot 10^{3}$ & 1.166 \\
\hline
\end{tabular}

\section{Analysis of the lead-acid battery operation while driving an electric vehicle}

The exemplary analysis of the lead-acid battery operation while driving an electric vehicle was carried out using the presented battery model and the estimated power demand of the vehicle. The estimation of the power demand was performed by recording the driving velocity (Fig. 8) of a real vehicle moving at the distance of $24.8 \mathrm{~km}$ at a time of

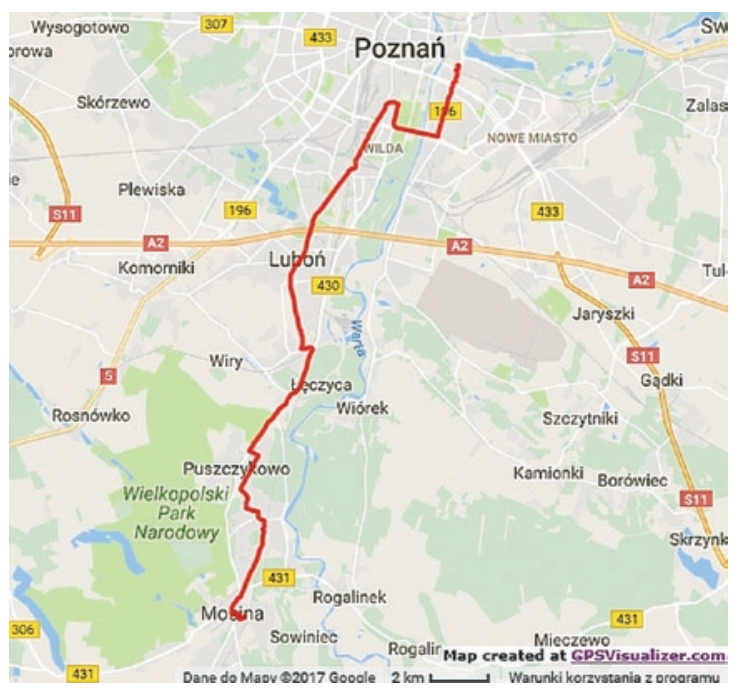

Fig. 9. The route on which the driving velocity was recorded

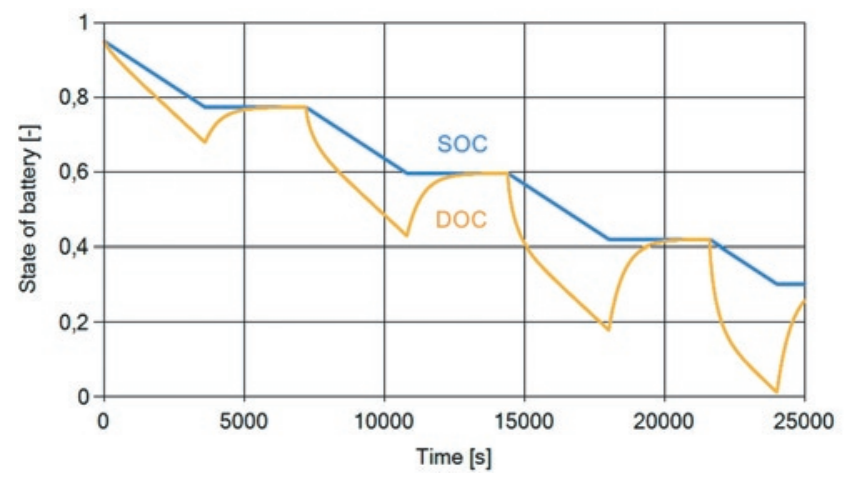

Fig. 7. Calculated battery state and depth vs time

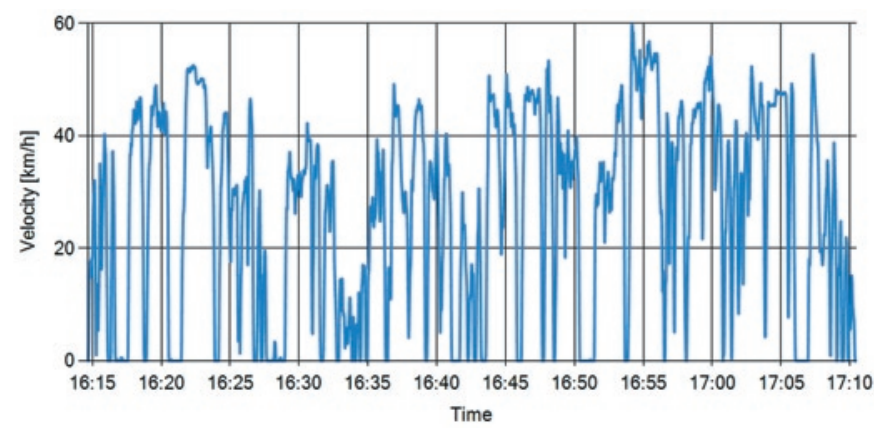

Fig. 8. Recorded velocity during a drive heavy traffic, with the average velocity of about $27 \mathrm{~km} / \mathrm{h}$. The course of the route during which the recording was made, is presented in figure 9.

Having the velocity, the vehicle accelerations were calculated and, by using the relations presented in section 3 (equations 1-6), all forces

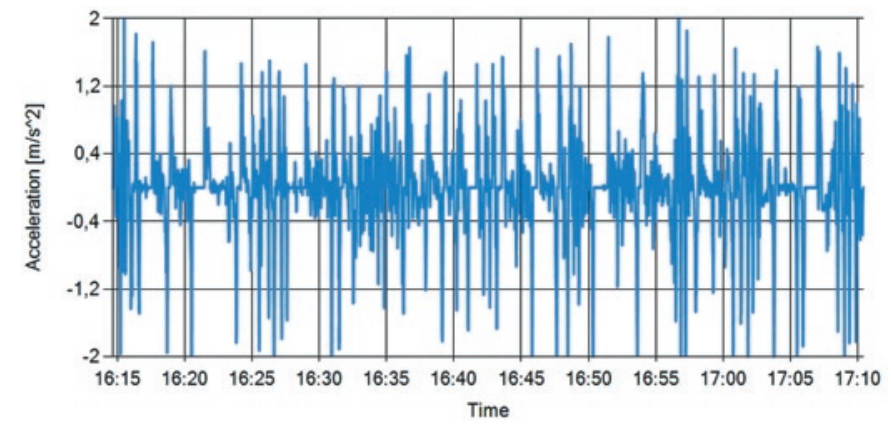

Fig. 10. Acceleration of the car vs drive time

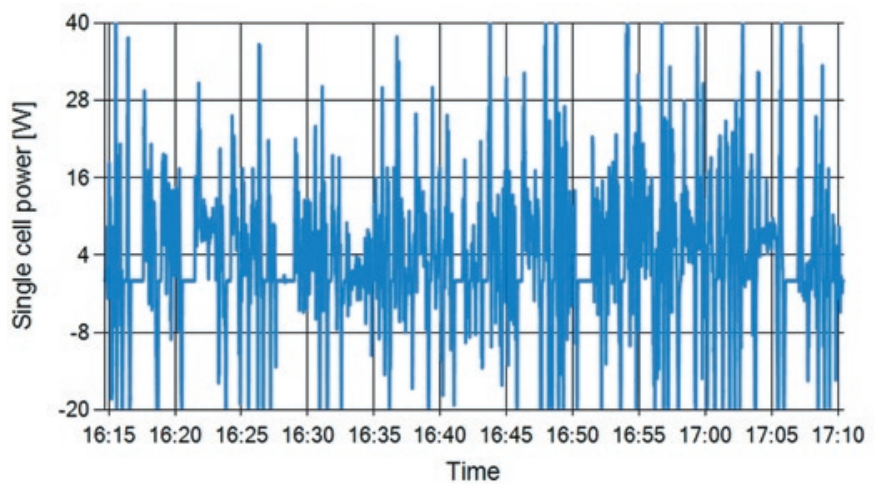

Fig. 11. Single cell power vs drive time - the positive power means that the car is speeding up (battery is discharging), while negative power means that the caris slowing down (battery is charging) 


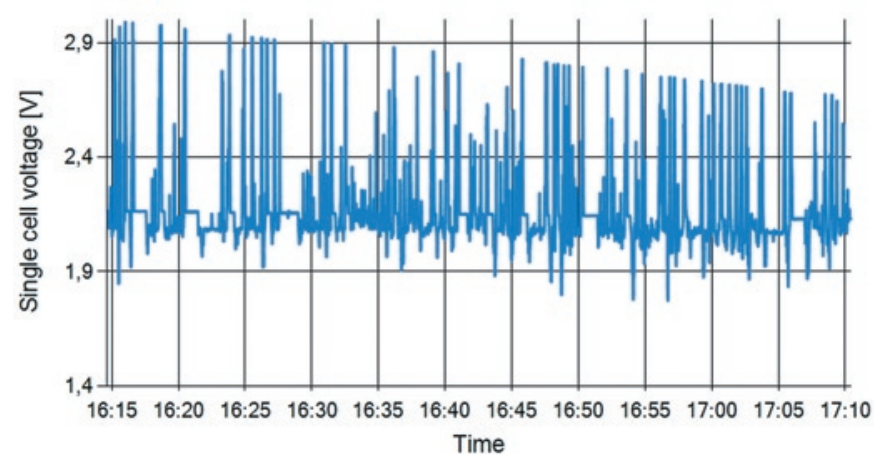

Fig. 12. Calculated voltage on a single cell vs drive time

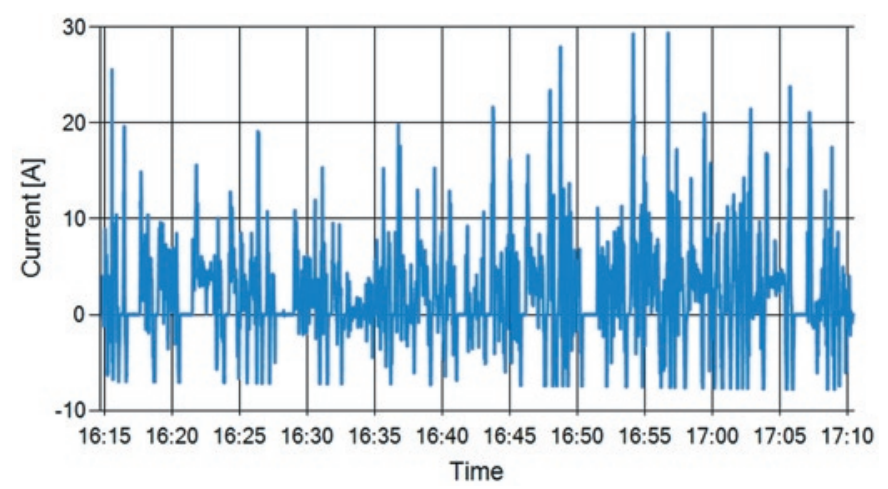

Fig. 13. Calculated current flowing through a single cell vs drive time

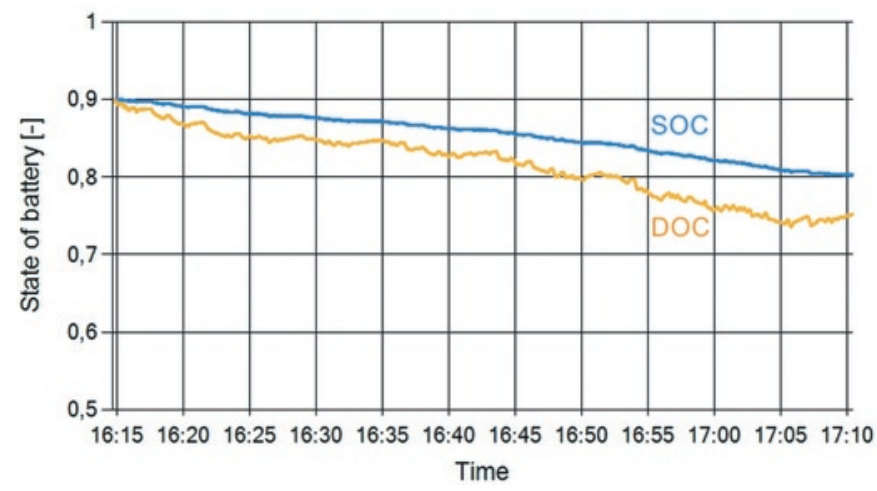

Fig. 14. Calculated battery state and depth of charge vs drive time

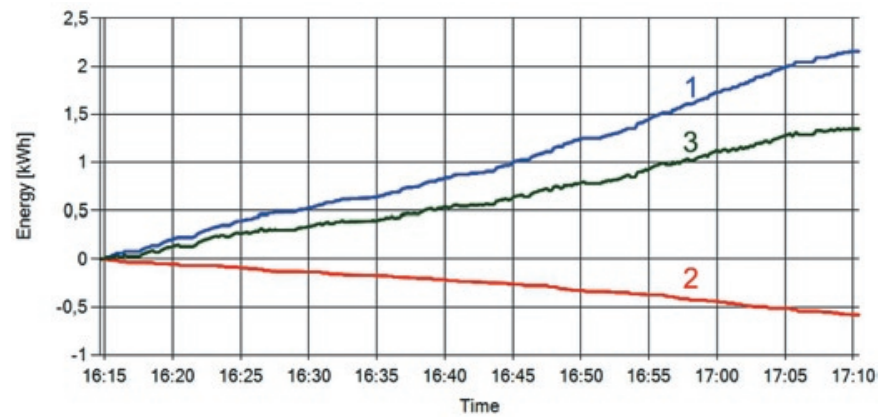

Fig. 15. Energy balance during the vehicle movement 1) speeding-up energy, 2) recoverable energy during the braking process, 3) resultant energy

acting on the car as well as momentary power required to move on the asphalt surface with the vehicle with the assumed weight of $1000 \mathrm{~kg}$ and frontal surface equal to $2 \mathrm{~m}^{2}$ were determined. The accelerations and single cell momentary power demand are presented in figure 10 and 11 , respectively.

During the analysis of the battery operation, voltages and currents

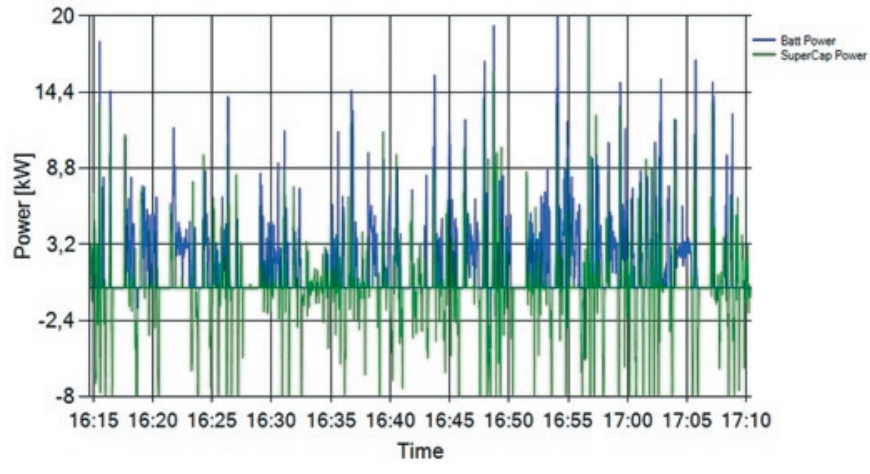

Fig. 16. Calculated power on a battery and supercapacitor vs drive time

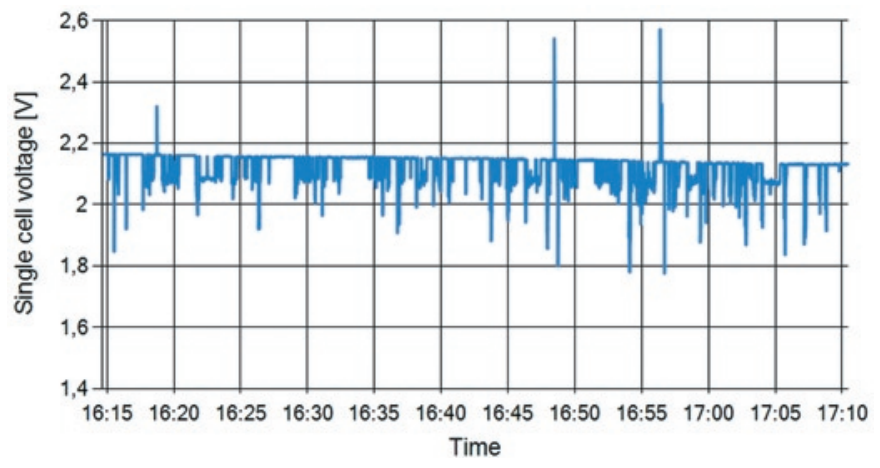

Fig. 17. Calculated voltage on a single cell vs drive time

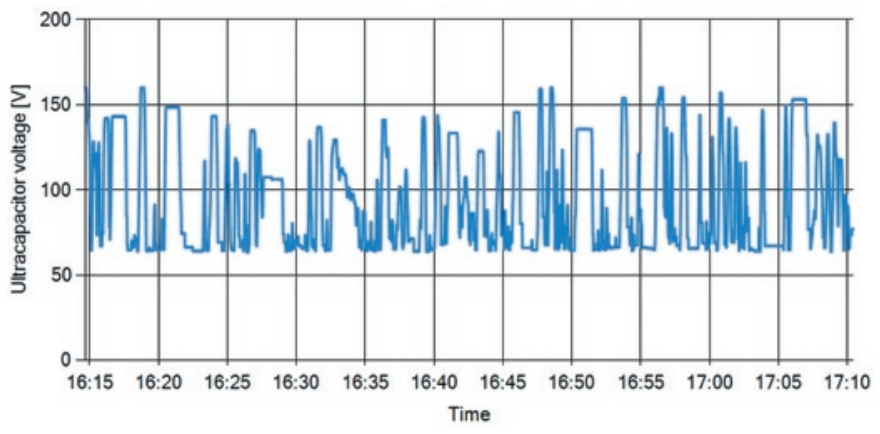

Fig. 18. Calculated voltage on the supercapacitor vs drive time

on the respective elements of the equivalent circuit as well as the battery state and depth of charge were determined for the assumed initial battery charge level equal to $90 \%$. These values are presented in figures 12 - 14 .

The next step was the determination of the total energy consumed by the vehicle under consideration, both the positive one - needed to speed up the vehicle, the negative one - recoverable during the braking process, and the resultant one - being the sum of both of these energies (the energy which would be consumed by the vehicle during its movement, with the system that allows for charging of the battery during the regenerative braking). The results of the obtained calculations are presented in figure 15.

The calculated voltage on battery terminals presented in figure 12 is characterised by numerous variations of values, resulting from the heavy regenerative braking, which adversely affects the battery and would cause the shortening of its life. Therefore, in real systems, such overvoltages are not allowed and traditional mechanical brakes are used during heavy braking (without the possibility of regeneration of the vehicle's kinetic energy).

For this reason, the use of an additional energy storage which would allow for taking over high currents flowing during the heavy regenerative braking (storages with high power density) is proposed 
in innovative solutions. In the present article, the BMOD0006 E160 B02 supercapacitor module manufactured by Maxwell was selected for this purpose. Its rated voltage amounts to $160 \mathrm{~V}$, its capacity is $11.6 \mathrm{~F}(0.35 \mathrm{Wh})$, and its inner resistance $\left(\mathrm{ESR}_{\mathrm{DC}}\right)$ is equal to $0.34 \Omega$. The module is adapted to operation within a broad temperature range (from -40 to $+60^{\circ} \mathrm{C}$ ). Then, the calculations related to the recorded driving route were repeated for the selected hybrid energy storage. An assumption was made during the analysis that the power electronics systems enable the use of the supercapacitor within the voltage range from 60 to $160 \mathrm{~V}$. The calculated power and voltage values on the respective energy storages are presented in figures 16-18.

While comparing voltages on a single cell of the battery operating independently and in the hybrid system with the supercapacitor (Fig. 12 and 17) it is possible to notice that the addition of the supercapacitor caused a significant reduction in high voltages on the battery terminals (only a few characteristic peaks were left). This follows from the fact that the supercapacitor takes over high flowing currents during the regenerative braking. This effect is visible in figure 16, in which power values on the respective energy storages were presented. Owing to the more effective use of energy during the regenerative braking, also the energy drawn from the battery was decreased, which can be noticed by comparing the average voltage value on cell terminals presented in figures 11 and 17 . The result is that the supercapacitor was used while driving in the majority of cases of regenerative braking, and then its energy was used during the vehicle acceleration. This provides evidence of the proper selection of the hybrid energy storage for the electric vehicle.

\section{Summary and conclusions}

The article presents methods of analysis of operation of energy storages used in electric vehicles. The modelling of the operation of energy storages is an important and valid issue, which concerns the electric vehicles, but also the systems which operate together with renewable energy sources and all types of electronic mobile devices (telephone sets, portable computers, etc.) sensitive to instabilities of the energy source performance.

Particular attention was paid in the paper to the issues concerning the estimation of the parameters of the mathematical model. For this purpose, the author has developed his own computer application, which enables the calculations of the equivalent circuit parameters based on the conducted measurements of voltage and current flowing through the battery. The performed computer calculations were confirmed by comparing them to the measured values (Fig. 6).

The main body of the paper also presents the problems related to energy consumption of vehicles and the energy storage load resulting from it. The recording of the velocity of the vehicle, which was moving along a route characterised by heavy traffic allowed for the modelling of the tested battery behaviour. The analysis demonstrated that the regenerative braking process may cause excessively intensive battery charging (Fig. 12), which would cause the systematic degradation of cells, and as a consequence of this, fast reduction of their ability to accumulate and transfer electric energy. In reality, such states in vehicles are not allowed owing to the use of mechanical brakes during the braking process, and the reduction of the amount of recovered energy.

The paper also presents the analysis of the hybrid storage consisting of an identical battery and a supercapacitor, which constitutes an energy storage of the vehicle moving along the same route. The conducted calculations demonstrated that the use of additional storage (supercapacitor) with much higher power density than the basic storage (battery), may significantly reduce high currents flowing through the battery and thus extend its life. Such a solution during an investment would require increased expenditure related to the purchase, but may turn out to be advantageous during operation both in the economic and ecological aspects. Further studies related to energy storages in electric vehicles will be aimed at improvement of the performance and life of various types of lithium batteries.

\section{Acknowledgement}

The author would like to thank Grzegorz Lota, Marek Baraniak and Damian Burzyński from the Poznan University of Technology for performing the measurements realized in the laboratory of the Institute of Chemistry and Technical Electrochemistry.

\section{References}

1. Achaibou N, Haddadi M, Malek A. Lead acid batteries simulation including experimental validation, Journal of Power Sources 2008; 185(2): 1484-1491, https://doi.org/10.1016/j.jpowsour.2008.06.059.

2. Barsali S, Ceraolo M. Dynamical Models of Lead-Acid Batteries: Implementation Issues, IEEE Transactions On Energy Conversion 2002; 17(1): 16-23, https://doi.org/10.1109/60.986432.

3. Bednarek K, Jajczyk J. Effectiveness of optimization methods in heavy-current equipment designing, Przeglad Elektrotechniczny 2009; 85(12): 29-32.

4. Bottiglione F, Pinto S D, Mantriota G, Sorniotti A. Energy Consumption of a Battery Electric Vehicle with Infinitely Variable Transmiossion, Energies 2014; 7(12): 8317-8337, https://doi.org/10.3390/en7128317.

5. Bugała A, Frydrychowicz-Jastrzębska G, Zbytek A, Dach J, Janczak D. Long-term performance evaluation of a fixed and solar follow - up systems with modified astronomical positioning in Polish conditions, MATEC Web of Conferences 2016; 5, https://dx.doi.org/10.1051/ matecconf/20165903004.

6. Ceraolo M. New dynamical models of lead-acid batteries, IEEE Transactions On Power Systems 2000; 15(4): 1184-1190, https://doi. org $/ 10.1109 / 59.898088$.

7. De Cauwer C, Van Mierlo J, Coosemans T. Energy Consumption Prediction for Electric Vehicles based On Real-World Data, Energies 2015; 8(8): 8573-8593.

8. Gu R, Malysz P, Wang D, Wang W, Yang H, Emadi A. On the design of a direct cell coupled hybrid energy storage system for plug-in hybrid electric vehicles, 2016 IEEE Transportation Electrification Conference and Expo (ITEC), Dearborn 2016; 1-7, https://doi.org/10.1109/ ITEC.2016.7520298.

9. He H, Xiong R, ChangY, Dynamic modeling and simulation on a hybrid power system for electric vehicle applications, Energies 2010; 3(11): 1821-1830, https://doi.org/10.3390/en3111821.

10. Itani K, De Bernardinis A, Khatir Z, Jammal A, Oueidat M. Extreme conditions regenerative braking modeling, control and simulation of a hybrid energy storage system for an electric vehicle, IEEE Transactions on Transportation Electrification 2016; PP(99): 1-1, https://doi. org/10.1109/TTE.2016.2608763. 
11. Jackey R, Saginaw M, Sanghvi P, Gazzarri J, Huria T, Ceraolo M. Battery Model Parameter Estimation Using a Layered Technique: An Example Using a Lithium Iron Phosphate Cell, SAE Technical Paper 2013-01-1547, 2013; https://doi.org/10.4271/2013-01-1547.

12. Jarzębowicz L, Kulig E, Analiza energochłonności pojazdu elektrycznego w oparciu o dane z pokładowego rejestratora parametrów, TTS Technika Transportu Szynowego 2015; 706-710.

13. Kasprzyk L, Bednarek K. Speeding up of electromagnetic and optimization calculations by the use of the parallel algorithms, Przeglad Elektrotechniczny 2009; 85(12): 65-68.

14. Kasprzyk L, Tomczewski A, Bednarek K. Efficiency and economic aspects in electromagnetic and optimization calculations of electrical systems, Przeglad Elektrotechniczny 2010; 86(12): 57-60 (in Polish).

15. Kasprzyk L. Analysis of energy recovery possibilities from motor vehicles, Przeglad Elektrotechniczny 2014; 90(4): 235-238.

16. Kasprzyk L. Electric cars and problem of energy storage selection with environment protection aspects, in: J. Maj, P. Kwiatkiewicz, R. Szczerbowski (Eds), Europejski Wymiar Bezpieczeństwa Energetycznego a Ochrona środowiska, Wojskowa Akademia Techniczna, Poznań 2015; 691-708 (in Polish).

17. Kasprzyk L. Analysis of a light field with the use of parallel computers, Przeglad Elektrotechniczny 2007; 83(12): 128-131 (in Polish).

18. Lombardi P, Röhrig C, Rudion K, Marquardt R, Müller-Mienack M, Estermann A S, Styczynski Z A, Voropai N I. An A-CAES pilot installation in the distribution system: A technical study for RES integration, Energy Science and Engineering 2014; 2(3): 116-127, https:// doi.org/10.1002/ese3.38.

19. Statistical pocketbook 2015. The European Council On Clean Transport 2016; http://www.theicct.org (access: 01.09.2016).

20. Wenge C, Arendarski B, Haensch K, Naumann A, Komarnicki P. Electric vehicle simulation models for power system applications, IEEE Power and Energy Society General Meeting, IEE, San Diego 2012: 1-6, https://doi.org/10.1109/PESGM.2012.6344942.

21. Wu X, Freese D, Cabrera A, Kitch W A Electric vehicles' energy consumption measurement and estimation, Transportation Research Part D 2015; 34: 52-67, https://doi.org/10.1016/j.trd.2014.10.007.

22. Zhan C J, Wu X G, Kromlidis S, Ramachandaramurthy V K, Barnes M, Jenkins N, Ruddell A J. Two electrical models of the lead-acid battery used in a dynamic voltage restorer, IEE Proceedings - Generation, Transmission and Distribution 2003; 150(2): 175-182, https://oi. org/10.1049/ip-gtd:20030124.

\author{
Leszek KASPRZYK \\ Institute of Electrical Engineering and Electronics \\ Poznan University of Technology \\ ul. Piotrowo 3A, 60-965 Poznan, Poland \\ E-mail: leszek.kasprzyk@put.poznan.pl
}

